\title{
EVALUATION OF ANTI-HYPERTROPHIC POTENTIAL OF PIPER BETLE IN ISOPROTERENOL-INDUCED CARDIAC HYPERTROPHIC RAT MODELS
}

\author{
DOSS VA *, MANJU VIDHYA SAKTHIKUMAR, DHARANIYAMBIGAI KUBERAPANDIAN
}

Department of Biochemistry, PSG College of Arts and Science, Coimbatore, Tamil Nadu, India. Email: victordoss64@gmail.com

Received: 12 April 2019, Revised and Accepted: 30 May 2019

ABSTRACT

Objective: The objective of this study was to evaluate the anti-hypertrophic potential of the combination extract (chloroform, methanol, and ethyl acetate) of Piper betle in cardiac hypertrophic rat models.

Methods: Isoproterenol (ISO) (10 mg/kg b. w., i.p., 7 days) was used to induce cardiac hypertrophy in male albino Wistar rats and simultaneously treated with the combination extract of P. betle (50 mg/kg b. w., oral, 7 days) and the standard drug losartan (50 mg/kg b. w., oral, 7 days) as reference. At the end of seventh day the biochemical estimations of glucose, protein, cholesterol, triglycerides, cardiac marker enzymes (SGOT, SGPT and LDH) and enzymic antioxidants (superoxide dismutase, catalase and glutathione peroxidase) were performed in the serum along with the targets of the study namely calcium and phosphorus. Heart tissues were subjected to histopathological analysis. All biochemical assays were statistically verified.

Results: The status of cardiac hypertrophy was indicated by the increased heart weight (HW)/body weight (BW) ratio. The biochemical assays showed significant $(\mathrm{p}<0.05)$ increase in the levels of glucose, protein, and cholesterol and in the cardiac marker enzymes such as SGOT, SGPT, and LDH, whereas significant decrease in the serum calcium and phosphorus along with antioxidants were seen in the ISO-induced rats and these levels were restored to normal values by the treatment with $P$. betle.

Conclusion: The combination extract of $P$. betle showed effect upon calcium and phosphorus levels besides reversing the other impacts of isoproterenol ( $\beta$-adrenergic hypersignaling events) probably due to phytoconstituents of the plant which are hypothesized to be efficiently extracted in combination of organic solvents, and thus, these results indicate that the combination extract of $P$. betle possesses cardioprotective (anti-hypertrophic) effect.

Keywords: Antioxidants, Cardiac hypertrophy, Isoproterenol, Piper betle, calcium, phosphorus.

(C) 2019 The Authors. Published by Innovare Academic Sciences Pvt Ltd. This is an open access article under the CC BY license (http://creativecommons. org/licenses/by/4. 0/) DOI: http://dx.doi.org/10.22159/ajpcr.2019.v12i7.33588

\section{INTRODUCTION}

Cardiac hypertrophy is a complex and relatively common cardiovascular disease with the prevalence of case reports from more than 50 countries [1]. "Cardiac hypertrophy is the abnormal enlargement or thickening of the heart muscle resulting from increase in cardiomyocyte size and change in other heart muscle components such as extracellular matrix due to pressure or elevated workload during development, pregnancy, and sustained exercise [2]. Cardiac hypertrophy ultimately leads to arrhythmic sudden death risk, progressive heart failure due to the left ventricular outflow obstruction or due to systolic dysfunction or atrial fibrillation with a risk of stroke. In the past decade, the identification and characteristics of the molecular signaling and metabolic pathways, leading to cardiac hypertrophy, has highlighted a number of potential therapeutic targets [3].

In recent years, the use of herbal medicine has been increased compared to synthetic drugs. $P$. betle belongs to the family of Piperaceae, which is an evergreen and perennial creeper with glossy heart-shaped leaves that contain a plethora of phenolic compounds such as eugenol, chavibetol, chavibetol acetate, and hydroxychavicol [4]. It is one of the most potent medicinal plants and is considered auspicious in India. $P$. betle leaves possess various medicinal and pharmacological properties such as antifertility, antiulcer, antiallergic, antibacterial, insecticidal, antioxidant, gastroprotective, anticancer, antinociceptive, antihypercholesterolemic, antidiabetic, immunomodulator, and wound healing activity [5-7].

\section{MATERIALS AND METHODS}

\section{Chemicals}

All the chemicals were purchased from HiMedia Laboratories, India, as analytical grade. ISO (Isoprenaline Hydrochloride) from SigmaAldrich. The standard drug losartan (50 mg tablets) was purchased commercially from local pharmacy, Coimbatore, India. The protein, glucose, cholesterol, triglyceride, and albumin estimation kits were purchased from Arkray Healthcare Pvt. Ltd., India. The SGOT, SGPT, and LDH kits were purchased from Agappe Diagnostics Ltd., India.

\section{Plant collection and extraction}

The leaves of the plant $P$. betle were collected from local areas (farms) of Krishnagiri district, Tamil Nadu, India, during the month of December and leaves were shade dried at room temperature. The dried whole plant was submitted and authenticated Botanical Survey of India (BSI/ SRC/5/23/2019/Tech/2691) at Botanical Survey of India, Southern Region Centre, Coimbatore, India. The dried leaves were coarse powdered and the preparation of combination extract of $P$. betle was done by cold macerating $(72 \mathrm{~h})$ plant powder using organic solvents (1:10 ratio) chloroform, methanol, and ethyl acetate, filtered after $72 \mathrm{~h}$ and condensed to dryness under controlled temperature. The yield thus obtained from each extract was weighed and mixed together in the ratio (1:1:1) and subjected to further analysis [8].

Quantification of phytochemicals

Phytochemicals present in the plant extract, namely carbohydrates (anthrone method), proteins (Lowry's method), total phenols 
(Folin-Ciocalteu method), tannins (Folin-Denis method), and flavonoids (Aluminum chloride method) were performed [9].

\section{Determination of free radical scavenging potentials of $P$. betle}

Free radical scavenging activity of the combination extract of $P$. betle was determined by 1,1-diphenyl-2-picrylhydrazyl (DPPH) scavenging assay [10] and nitric oxide free radical scavenging activity [11] with ascorbic acid as the standard for reference.

\section{Procurement of animals}

Male albino Wistar rats (100-150 g) were procured after the ethical clearance for handling of experimental animals from the Institutional Animal Ethics Committee (IAEC) as per the guidance of CPCSEA, Ministry of Social Justice and Empowerment, Government of India (CPCSEA/No 422/2019/IAEC) at the PSG Institute of Medical Sciences and Research, Coimbatore. The animals were acclimatized under standard laboratory conditions for 3 days with controlled temperature $\left(29^{\circ} \pm 5^{\circ} \mathrm{C}\right)$, humidity $(55 \% \pm 5 \%)$, and $12 \mathrm{~h}$ of light/ dark cycles.

\section{Experimental design}

The rats chosen for the study were divided into four groups of three animals in each group. ISO was used to induce cardiac hypertrophy and simultaneously treated with the reference drug losartan and the plant extract as shown in Table 1.

At the end of the experimental period ( 7 days), the animals were sacrificed using mild chloroform anesthesia. The blood was collected through cardiac puncture and the serum was separated by centrifugation at $5000 \mathrm{rpm}$ for $20 \mathrm{~min}$. The serum was then stored at $-20^{\circ} \mathrm{C}$ for further biochemical analysis.

\section{Hypertrophic indices}

The hypertrophic indices (HW; BW; and HW/BW ratio) were measured $[15,16]$

\section{Biochemical estimations}

Serum glucose was estimated by glucose oxidase method (Autospan Liquid Gold Glucose Kit), serum total protein by Lowry's method (Autospan), serum cholesterol by CHOD-PAP enzymatic endpoint assay method (Autospan), serum calcium by Arsenazo III method and serum phosphorous by molybdate ultraviolet method, and the estimation of SGOT and SGPT activities by modified IFCC method (Agappe) and LDH by optimized kinetic assay method (Agappe). The estimation of enzymatic antioxidants such as SOD [16], catalase [17], and GPx [18] was also performed in the serum.

\section{Histopathological analysis}

The rat hearts were excised and washed thoroughly with phosphatebuffered saline and immediately subjected to $10 \%$ formalin for preservation until the tissues were processed as transverse, $5 \mu \mathrm{m}$ thick paraffin, left ventricular sections. The dyes such as hematoxylin and eosin were used to stain these sections and they were magnified $(\times 40)$ for analyzing the cellular architecture of the heart tissues [19]

\section{Statistical analysis}

Data obtained from the results were expressed as mean SD. Statistical analysis was performed using Student's " $t$ "-test in IBM SPSS software (version 25.0 free trial, India) and the $\mathrm{p}<0.05$ was considered statistically significant [20].

\section{RESULTS AND DISCUSSION}

\section{Phytochemical evaluation}

The phytochemical qualitative screening of the combination extract of chloroform, methanol, and ethyl acetate showed the presence of primary metabolites such as carbohydrates and proteins and secondary metabolites such as phenols, alkaloids, saponins, tannins, glycosides, flavonoids, and sterols. The results of the quantitative estimations of carbohydrates, proteins, phenol, flavonoids, and tannins present in the
Table 1: Experimental models for induction and treatment of cardiac hypertrophy

\begin{tabular}{|c|c|}
\hline Groups & Experimental animals \\
\hline Group I & Normal control rats \\
\hline Group II & Isoproterenol (10 mg $/ \mathrm{kg}$ body weight, i.p., 7 days) [11] \\
\hline Group III & $\begin{array}{l}\text { Isoproterenol+losartan ( } 50 \mathrm{mg} / \mathrm{kg} \text { body weight, oral, } \\
7 \text { days) [12] }\end{array}$ \\
\hline Group IV & $\begin{array}{l}\text { Isoproterenol+combination of chloroform, methanol, } \\
\text { and ethyl acetate extract of Piper betle ( } 50 \mathrm{mg} / \mathrm{kg} \text { body } \\
\text { weight, oral, } 7 \text { days) [13] }\end{array}$ \\
\hline
\end{tabular}

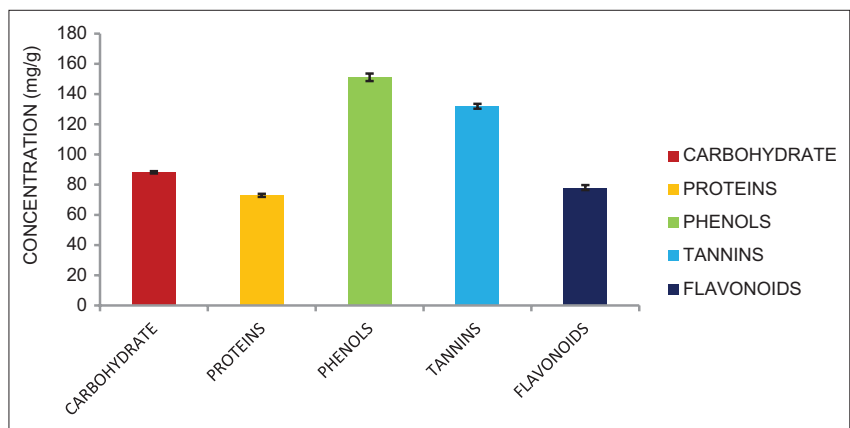

Fig. 1: Quantitative phytochemical analysis of combination leaf extract of $P$. betle

plant extract of $P$. betle are shown in Fig. 1. The phenolic compounds are one of the largest and most ubiquitous groups of plant metabolites and are attributed to the therapeutic activities of biological systems [21]. Tannins and flavonoids possess various biological activities such as anti-inflammatory, anticancer, and antioxidant properties that help in the prevention and treatment of numerous diseases [22]. These findings offer a scientific validation for the lead compound identification and further in vitro and in vivo studies.

\section{DPPH radical scavenging activity}

DPPH radical is being widely used as the model system to investigate the scavenging activities of several natural compounds. It was observed that this free radical was scavenged by the plant extract in a concentration-dependent manner. The maximum percentage (77\%) of DPPH radical scavenging activity was at $500 \mu \mathrm{g} / \mathrm{ml}$ concentration. It was compared with the standard ascorbic acid which showed $88 \%$ inhibition at the same concentration (Table 2). These findings were in accordance with a similar study [23] that reported the potent antioxidant activity shown by the betle leaves may be due to the phenolic compounds in the extract such as chavicol, chavibetol, chavibetol acetate, and eugenol.

\section{NO radical scavenging activity}

The percentage inhibition (highest to lowest) of combination leaf extract of $P$. betle varied from $81 \%$ to $51 \%$ at the concentration of $500-100 \mu \mathrm{g} / \mathrm{ml}$, respectively, when compared to the standard ascorbic acid $(90 \%-58 \%)$ at same concentration ranges (Table 2). These results are in correlation with a similar study [24] that stated this scavenging activity of $P$. betle may be due to the polyphenols and other biomolecules such as tannins and flavonoids present in the extract.

\section{Effect of ISO and plant extract on hypertrophic index}

The commonly used index of cardiac hypertrophy is the HW/BW ratio. In this study, there was no significant change in the BW, but an increase in the HW and HW/BW ratio (increased by 15\%) in the rats injected with ISO (Group II) was observed as evident from Table 3. However, rats treated with losartan (Group III) showed $15.85 \%$ reduction and also the rats treated with plant extract of P. betle (Group IV) showed 10.95\% reduction in the HW/BW ratio when compared to ISO administered rats. This shows the anti-hypertrophic potential of the plant extract and 
Table 2: Free radical scavenging ability of Piper betle

\begin{tabular}{llll}
\hline Sample & Concentration $(\mu \mathrm{g} / \mathbf{m l})$ & DPPH (percentage inhibition) & NO (percentage inhibition) \\
\hline Piper betle & 100 & 48 & 51 \\
& 200 & 53 & 59 \\
& 300 & 57 & 62 \\
Standard (ascorbic acid) & 400 & 66 & 73 \\
& 500 & 81 & 81 \\
& 100 & 52 & 58 \\
& 200 & 58 & 64 \\
& 300 & 61 & 81 \\
\hline
\end{tabular}

DPPH: 1,1-diphenyl-2-picrylhydrazyl

Table 3: Effect of Piper betle on the hypertrophic indices

\begin{tabular}{|c|c|c|c|c|}
\hline Parameter & Group I & Group II & Group III & Group IV \\
\hline Heart weight (mg) & $414 \pm 3.60$ & $510 \pm 2.25^{\mathrm{a} *}$ & $424 \pm 3.05^{\mathrm{a} *}$ & $422 \pm 1.05^{\mathrm{a} *}$ \\
\hline Body weight (g) & $110 \pm 5.03$ & $118 \pm 1.52^{\mathrm{a} *}$ & $117 \pm 2.08^{\mathrm{a} *}$ & $110 \pm 1.52^{\mathrm{a}}$ \\
\hline Heart weight/body weight (mg/g) & $3.73 \pm 0.15$ & $4.29 \pm 0.06^{\mathrm{a} *}$ & $3.61 \pm 0.09^{\mathrm{a} *}$ & $3.82 \pm 0.03^{a}$ \\
\hline
\end{tabular}

Values are explicit by mean \pm SD of three samples per group. Group comparison: a Normal (I) versus ISO (II); ${ }^{\mathrm{b}}$ ISO (II) versus losartan (III); ${ }^{\mathrm{I}}$ ISO (II) versus plant

extract (VI). Statistically significant denoted by*. SD: Standard deviation, ISO: Isoproterenol

Table 4: Effect of isoproterenol and Piper betle on serum levels of glucose, total protein, and total cholesterol

\begin{tabular}{llll}
\hline Groups & Glucose $(\mathbf{m g} / \mathbf{d l})$ & Total protein $\mathbf{( g / d )}$ & Total cholesterol $(\mathbf{m g} / \mathbf{d l})$ \\
\hline Group I & $92.33 \pm 1.66$ & $6.41 \pm 0.03$ & $122.27 \pm 1.38$ \\
Group II & $130.83 \pm 1.46^{\mathrm{a}}$ & $7.0 \pm 0.02^{\mathrm{a}}$ & $173.45 \pm 1.50^{\mathrm{a} *}$ \\
Group III & $161.75 \pm 1.39^{*}$ & $6.5 \pm 0.04^{\mathrm{b}}$ & $225.08 \pm 4.63^{\mathrm{b} *}$ \\
Group IV & $99.25 \pm 0.66^{*}$ & $6.55 \pm 0.03^{\mathrm{c}}$ & $102.37 \pm 1.11^{\mathrm{c} *}$ \\
\hline
\end{tabular}

Values are explicit by mean \pm SD of three samples per group. Group comparison: ${ }^{a}$ Normal (I) versus ISO (II); ${ }^{b}$ ISO (II) versus losartan (III); ${ }^{\text {ISO }}$ (II) versus plant extract (VI). Statistically significant denoted by*. SD: Standard deviation, ISO: Isoproterenol

Table 5: Effect of isoproterenol and Piper betle on calcium and phosphorous

\begin{tabular}{lll}
\hline Groups & Calcium $(\mathbf{m g} / \mathbf{d l})$ & Phosphorous $(\mathbf{m g} / \mathbf{d l})$ \\
\hline Group I & $8.89 \pm 0.12$ & $4.27 \pm 0.12$ \\
Group II & $4.93 \pm 0.15^{\mathrm{a} *}$ & $6.26 \pm 0.05^{\mathrm{a}}$ \\
Group III & $5.85 \pm 0.13^{\mathrm{b}}$ & $6.00 \pm 0.11^{\mathrm{b} *}$ \\
Group IV & $9.38 \pm 0.16^{\mathrm{c}}$ & $4.86 \pm 0.08^{\mathrm{c} *}$ \\
\hline
\end{tabular}

Values are explicit by mean \pm SD of three samples per group. Group comparison: ${ }^{a}$ Normal (I) versus ISO (II); ${ }^{b}$ ISO (II) versus losartan (III); ' ISO (II) versus plant extract (VI). Statistically significant denoted by*. SD: Standard deviation, ISO: Isoproterenol

these results are in correlation with a similar study [25].

Effect of ISO and plant extract on glucose, total protein, and cholesterol in serum

Cardiac hypertrophy is marked by increase in the levels of protein, glucose, and total cholesterol and the treatment of this disease should indicate the reciprocation of these elevated levels of biomolecules to the normal range. In ISO-induced rats, a mild increase in the protein levels and a significant increase in the glucose and total cholesterol levels were observed when compared to the normal rats. After oral administration of the combination extract of $P$. betle, there was a significant decrease in the levels of glucose, total protein, and total cholesterol when compared with Group II and these levels restored to the normal range as shown in Table 4. These results indicate the potential cardioprotective effect of the plant extract [26].

Effect of ISO and plant extract on calcium and phosphorous levels in the serum

The calcium ion is an essential regulator for diverse physiological processes including contraction of cardiac, skeletal and smooth muscle, and neurotransmitter release. Increase in calcium level is a potential trigger of the translocation of pro-hypertrophic transcription factors to the nucleus which is involved in the development of cardiac muscle [27]. Serum phosphorous concentration is tightly regulated and the concentration is dependent on its intestinal absorption, utilization, and renal excretion. An increase in the serum phosphorus level even within the normal range is associated with the left ventricular hypertrophy and greater risk of developing cardiovascular disease [28]. In this study (Table 5), there was a slight decrease in the level of calcium in ISO-induced cardiac hypertrophic rats (Group II) and an mild increase in the losartan-treated rats (Group III) and these levels were restored to normal range in the plant extract administered rats (Group IV). The low calcium level in ISO-induced rats may be due to secondary hyperparathyroidism caused by Vitamin D deficiency and/ or renal dysfunction [29].

Increased serum phosphorous levels in group II of isoproterenol administered rats were observed when compared to the normal control rats (group I) and the levels were reciprocated to normal range in the rats treated with combination extract of $P$. betle (group IV).

\section{Effect of ISO and plant extract on cardiac marker enzymes}

Cardiac hypertrophy is indicated by the elevated levels of cardiac marker enzymes in the serum and is also an indication of cardiovascular events like myocardial infarction [30]. The ISO-administered rats showed a significant elevation in the levels of cardiac marker enzymes such as SGOT, SGPT, and LDH indicating cardiac hypertrophy, whereas the treatment of experimental animals with the reference drug losartan and combination extract of $P$. betle was able to restore levels of these cardiac enzymes to the normal range, indicating the anti-hypertrophic potential of the plant extract as shown in Table 6.

Effect of ISO and plant extract on enzymatic antioxidants Superoxide radicals released by oxidative phosphorylation are 
detoxified with the help of SOD in the first step of converting them to hydrogen peroxide followed by the action of catalase and various peroxidases (preferably GPx). An imbalance in the generation of superoxides and its detoxification can result in the accumulation of $\mathrm{H}_{2} \mathrm{O}_{2}$ which leads to the production of highly reactive hydroxyl radicals causing oxidative stress and lipid peroxidation [31]. In ISO-induced cardiac hypertrophic rats (Group II), the antioxidant enzymes such as catalase, SOD, and GPx were significantly decreased considerably when compared with that of the normal group (Group I). Oral administration

Table 6: Effect of isoproterenol and Piper betle on serum levels of serum glutamic oxaloacetic transaminase, serum glutamic pyruvic transaminase, and lactate dehydrogenase

\begin{tabular}{llll}
\hline Groups & SGOT (U/L) & SGPT (U/L) & LDH $(\mu$ kat/l) \\
\hline Group I & $6.61 \pm 0.36$ & $7.26 \pm 0.12$ & $84.47 \pm 1.12$ \\
Group II & $8.72 \pm 0.03^{\mathrm{a}}$ & $9.62 \pm 0.38^{\mathrm{a}}$ & $114.45 \pm 1.37^{\mathrm{a} *}$ \\
Group III & $5.27 \pm 0.12^{\mathrm{b}}$ & $7.83 \pm 0.04^{\mathrm{b}}$ & $100.01 \pm 1.25^{\mathrm{b} *}$ \\
Group IV & $5.25 \pm 0.05^{\mathrm{c}}$ & $6.58 \pm 0.11^{\mathrm{c}}$ & $85.29 \pm 0.62^{\mathrm{c}}$ \\
\hline
\end{tabular}

Values are explicit by mean \pm SD of three samples per group. Group comparison: ${ }^{a}$ Normal (I) versus ISO (II); bISO (II) versus losartan (III); cISO (II) versus plant extract (VI). Statistically significant denoted by*. SGOT: Serum glutamic oxaloacetic transaminase, SGPT: Serum glutamic pyruvic transaminase, LDH: Lactate dehydrogenase, SD: Standard deviation, ISO: Isoproterenol

Table 7: Effect of isoproterenol and Piper betle on serum levels of enzymatic antioxidants

\begin{tabular}{llll}
\hline Groups & SOD (IU/L) & GPx (IU/L) & CAT (IU/L) \\
\hline Group I & $54.80 \pm 1.76$ & $26.50 \pm 0.90$ & $37.80 \pm 2.27$ \\
Group II & $29.02 \pm 1.59^{\mathrm{a}, *}$ & $12.86 \pm 1.20^{\mathrm{a} *}$ & $10.17 \pm 0.97^{\mathrm{a} *}$ \\
Group III & $42.20 \pm 1.34^{\mathrm{b} *}$ & $26.76 \pm 1.43^{\mathrm{b} *}$ & $22.12 \pm 0.88^{\mathrm{b} *}$ \\
Group IV & $46.37 \pm 1.23^{\mathrm{c} *}$ & $19.17 \pm 0.38^{\mathrm{c} *}$ & $19.12 \pm 0.53^{\mathrm{c} *}$ \\
\hline
\end{tabular}

Values are explicit by mean \pm SD of three samples per group. Group comparison:

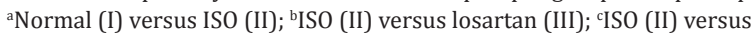
plant extract (VI). Statistically significant denoted by*. SOD: Superoxide dismutase, GPx: Glutathione peroxidase, CAT: Catalase, SD: Standard deviation, ISO: Isoproterenol

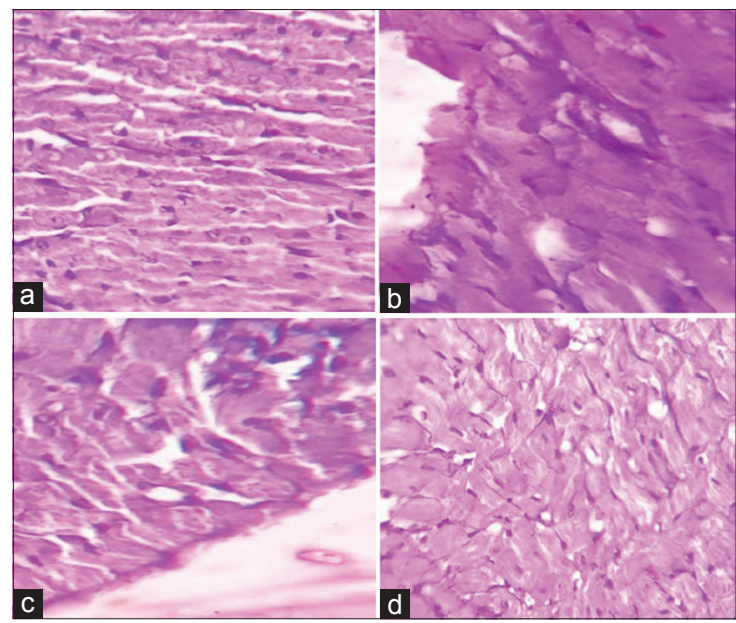

Fig. 2: Histopathological analysis $(\mathrm{H}$ and $\mathrm{E}$ stain, $\times 40)$ of heart tissues (left ventricle). (a) Group I (normal) showed a clear, intact homogenous myofibril arrangements which indicates no sign of inflammation. (b) Group II (ISO) revealed degeneration of myofibrillary arrangements with loss of usual parallel arrays accompanied by the appearance of thick tissue deposition and the presence of inflammatory cell infiltration (c) Group III (ISO+ losartan) showed rejuvenation of the myofibril arrangement tissue rejuvenation similar to that of normal can be seen. (d) Group IV (ISO + Piper betle) showed reduction in the cellular necrosis, infiltrations and tissue depositions were observed. of the combination leaf extract of $P$. betle $(50 \mathrm{mg} / \mathrm{kg})$ and losartan increased the concentration of antioxidants. The enzymatic antioxidant levels were restored in experimental animals to the range of normal control (Group I) as shown in Table 7.

\section{Histopathological observations}

Histopathological analysis of the heart tissues (left ventricle) showed deleterious modifications in the cardiac hypertrophic heart tissues induced by ISO and these impacts were repaired in the rats treated with losartan and the combination extract of $P$. betle for a period of 7 days as shown in (Fig. 2a-d) [19].

In Fig. 2a, Group I (normal) showed a clear, intact homogenous myofibril arrangements which indicates no sign of inflammation. In Fig. 2b, Group II (ISO) revealed degeneration of myofibrillary arrangements with loss of usual parallel arrays accompanied by the appearance of thick tissue deposition and the presence of inflammatory cell infiltration. In Fig. 2c, Group III (ISO+ losartan) showed rejuvenation of the myofibril arrangement tissue rejuvenation similar to that of normal can be seen. In Fig. 2d, Group IV (ISO + P. betle) showed reduction in the cellular necrosis; infiltrations and tissue depositions were observed.

\section{CONCLUSION}

This study implies that the combination extract of $P$. betle possesses anti-hypertrophic potential through its antioxidant property which was demonstrated by the radical scavenging activity the ability to restore the impaired levels of glucose, protein, and cardiac marker enzymes (SGOT, SGPT, and LDH). To add, this study also suggests that calcium and phosphorus can be considered as a screening risk marker for the occurrence of hypertrophy and during evaluations of anti-hypertrophic. This anti-hypertrophic potential of combination extract of $P$. betle could be due to the phytochemical compounds such as eugenol and hydroxychavicol that are mostly isolated using the solvents of study and further studies can be taken for the identification, isolation, and characterization of these compounds which may possess cardioprotective effect.

\section{AUTHORS CONTRIBUTION}

Dr. Victor Arokia Doss was the supervisor of this work that was carried out by Manju Vidhya Sakthikumar. Dharaniyambigai K planned the project along with Dr. Victor and helped in carrying out experiments and drafted the manuscript prepared by Manju Vidya.

\section{ACKNOWLEDGMENT}

The authors would like to thank PSG Institute of Medical Sciences and Research and PSG IAEC, Coimbatore, India, and the committee for the purpose of Control and Supervision of Experiments on Animals for providing animal ethical clearance. Sincere thanks to BSI for the plant authentication. The authors would like to thank Ponmani and Co. Pvt. Ltd., Coimbatore, Arkray and Agappe Diagnostics Pvt. Ltd., India, for kits for providing ISO (Sigma) and the biochemical kits, respectively. The authors would like to thank Ratthan Laboratory, Coimbatore, for aiding with histopathological facilities.

\section{CONFLICTS OF INTEREST}

The authors report no conflicts of interest.

\section{REFERENCES}

1. Maron BJ. Hypertrophic cardiomyopathy: A systematic review. JAMA 2002;287:1308-20.

2. Rothermel BA, Berenji K, Tannous P, Kutschke W, Dey A, Nolan B, et al. Differential activation of stress-response signaling in load-induced cardiac hypertrophy and failure. Physiol Genomics 2005;23:18-27.

3. Rohini A, Agarwal N, Chandrasekar NJM aand Sara SVU. Evaluation of cardioprotective effect of Zingiber officinale in experimental animals. IJCPR 2013;4:1-9.

4. Rekha VP, Kollipara M, Gupta S, Bharath Y, Pulicherla KK. A review 
on Piper betle L.: Nature's promising medicinal reservoir. Am J Ethnomed 2014;1:276-89.

5. Patra B, Das MT, Dey SK. A review on Piper betle L. J Med Plants Stud 2016;4:185-92.

6. Saini S, Dhiman A, Nanda S. Pharmacognostical and phytochemical studies of Piper betle Linn Leaf. Int J Pharm Pharm Sci 2016;8:222-6.

7. Chakraborty D, Shah B. Anti-microbial, antioxidative and antihemolytic activity of Piper betle extracts. Int J Pharm Pharm Sci 2011;3:192-9.

8. Murali B, Upadhyaya UM, Goyal RK. Effect of chronic treatment with Enicostemma littorale in non-insulin-dependent diabetic (NIDDM) rats. J Ethnopharmacol 2002;81:199-204

9. Gracelin SH, De Britto JA, Benjamin P, Kumar RJ. Qualitative and quantitative analysis of phytochemicals in five Pteris species. Int $\mathrm{J}$ Pharm Pharm Sci 2012;5:105-7.

10. Chang ST, Wu JH, Wang SY, Kang PL, Yang NS, Shyur LF, et al. Antioxidant activity of extracts from Acacia confusa bark and heartwood. J Agric Food Chem 2001;49:3420-4.

11. Rai S, Wahile A, Mukherjee K, Saha BP, Mukherjee PK. Antioxidant activity of Nelumbo nucifera (sacred lotus) seeds. J Ethnopharmacol 2006;104:322-7.

12. Zhang S, Tang F, Yang Y, Lu M, Luan A, Zhang J, et al. Astragaloside IV protects against isoproterenol-induced cardiac hypertrophy by regulating $\mathrm{NF}-\kappa \mathrm{B} / \mathrm{PGC}-1 \alpha$ signaling mediated energy biosynthesis. PLoS One 2015; 10:e0118759.

13. Jordi GG, Guash E, Benito B, Brugada J, Nattel S, Mont L and Mollar AS. Losartan prevents heart fibrosis induced by long-term intensive exercise in an animal model. PLoS One 2013;8:e55427.

14. Lien LT, Tho NT, Ha DM, Hang PL, Nghia PT, Thang ND, et al. Influence of phytochemicals in Piper betle Linn leaf extract on wound healing. Burns Trauma 2015;3:23.

15. Doss VA, Parthibhan J, Kuberapandian D. Evaluation of antihypertrophic potential of Camellia sinensis in isoproterenol induced cardiac hypertrophy. Int J Pharm Pharm Sci 2018;10:119-23.

16. Kakkar P, Das B, Viswanathan PN. A modified spectrophotometric assay of superoxide dismutase. Indian J Biochem Biophys 1984;21:130-2.

17. SinhaAK. Colorimetric assay of catalase.Anal Biochem 1972;47:389-94.

18. Rotruck JT, Pope AL, Ganther HE, Swanson AB, Hafeman DG, Hoekstra WG, et al. Selenium: Biochemical role as a component of glutathione peroxidase. Science 1973;179:588-90.

19. Al-Rasheed NM, Al-Oteibi MM, Al-Manee RZ, Al-Shareef SA, AlRasheed NM, Hasan IH, et al. Simvastatin prevents isoproterenol- induced cardiac hypertrophy through modulation of the JAK/STAT pathway. Drug Des Devel Ther 2015;9:3217-29.

20. Snedecor GW, Cochran WG. Shortcut and Non-parametric Methods. In: Statistical Methods. New York: Oxford and IBH; 1986.

21. Njoku PC, Akumefula MI. Pak J Nutr 2007;6:613-15.

22. James DB, Abu EA, Wurochekk AU, Orji GN. Phytochemical and antimicrobial investigation of the aqueous and methanolic extracts of Ximenia Americana. J Med Sci 2007;7:284-8

23. Rathee JS, Patro BS, Mula S, Gamre S, Chattopadhyay S. Antioxidant activity of piper betel leaf extract and its constituents. J Agric Food Chem 2006;54:9046-54

24. Nazira A, Kanthimani MS, Aziz AA. Piper betle shows antioxidant activities, inhibits MCF-7 cell proliferation and increases activities of catalase and superoxide dismutase. BMC Complement Altern Med 2012;12:220

25. Ennis IL, Escudero EM, Console GM, Camihort G, Dumm CG, Seidler RW, et al. Regression of isoproterenol-induced cardiac hypertrophy by na $+\mathrm{H}+$ exchanger inhibition. Hypertension 2003;41:1324-9.

26. Doss VA, Kuberapandian D. Evaluation of anti-hypertrophic potential of Enicostemma littorale blume on isoproterenol induced cardiac hypertrophy. Indian J Clin Biochem 2019. Avaliable online: https://doi. org/10.1007/s12291-019-0814-x

27. Patel VB, Vacek JL, Graves L, Bhattacharya RK. Calcium affects on vascular endpoints. Nutr Metab (Lond) 2012;9:24.

28. Dhingra R, Gona P, Benjamin EJ, Wang TJ, Aragam J, D'Agostino RB, et al. Relations of serum phosphorus levels to echocardiographic left ventricular mass and incidence of heart failure in the community. Eur J Heart Fail 2010;12:812-8.

29. Tomasello S. Secondary hyperparathyroidism and chronic kidney disease. Diabetes Spectrum 2008;21:19-25.

30. Saxena R, Wijnhoud AD, Man in 't Veld AJ, van den Meiracker AH, Boomsma F, Przybelski RJ, et al. Effect of diaspirin cross-linked hemoglobin on endothelin-1 and blood pressure in acute ischemic stroke in man. J Hypertens 1998;16:1459-65.

31. AliMS, MudagalMP, GoliD.Cardioprotective effect of tetrahydrocurcumin and rutin on lipid peroxides and antioxidants in experimentally induced myocardial infarction in rats. Pharmazie 2009;64:132-6.

32. Padma VV, Poornima P, Prakash C, Bhavani R. Oral treatment with gallicnacid and quercetin alleviates lindane-induced cardiotoxicity in rats. Can J Physiol Pharmacol 2013;91:134-40. 